\title{
PEMBERIAN PENGAMPUNAN ANTARPRIBADI MENURUT EVERETT L. WORTHINGTON DAN CHARLES L. GRISWOLD
}

\section{Diana Bachri}

Sekolah Tinggi Filsafat Driyarkara Jakarta, Indonesia

Email: dianabachri2@gmail.com

\begin{abstract}
Abstrak
Tidak mudah memberi pengampunan antarpribadi, terlebih dari pihak subyek sebagai korban kekerasan. Penelitian psikologis dengan pendekatan kualitatif terhadap perempuan korban kekerasan di masa anak memperlihatkan, tidak ditemukannya kesediaan mengampuni secara total sesuai teori pengampunan Worthington. Sebagai tindak-lanjut dari penelitian lapangan, ditelusuri argumentasi mendasar ketidak-mampuan atau ketidak-bersediaan subyek memberi pengampunan antarpribadi. Penelusuran ini membutuhkan kajian filosofis dengan memperhatikan berbagai argumentasi antropologis-etis. Mengapa tidak mudah memberi pengampunan antarpribadi, dan bagaimana penjelasan etis untuk menjawab permasalahan tidak mampu memberi pengampunan; inilah tujuan penelitian penulis. Pengampunan antarpribadi mampu diberikan subyek penyintas kekerasan, sebab mengandaikan masih terdapat luka, kemarahan dan perasaan sakit-hati terhadap pelaku kejahatan. Penjelasan filosofis Griswold mampu menjawab adanya kesulitan memberi pengampunan antarpribadi sehingga melengkapi teori psikologis Worthington tentang memberi pengampunan antarpribadi. Dengan memahami terdapat kesulitan memberi pengampunan antarpribadi, maka menjadi penting dilatih suatu kesediaan memberi pengampunan sedini mungkin, guna membangun habitus atau kebiasaan yang baik yaitu bersedia mengampuni sesama manusia secara antarpribadi dalam hidup sehari-hari.
\end{abstract}

Kata kunci: pengampunan antarpribadi, pengampunan tidak sempurna (nonparadigmatic forgiveness), keutamaan moral, pembiasaan (habitus)

\begin{abstract}
Giving interpersonal forgiveness requires a struggle to manage emotions, changing from negative to positive emotions; Worthington's psychological understanding requires philosophical awareness in order for survivors to be able to forgive the perpetrators of evil. Griswold, a 21st-century philosopher, explained that forgiveness actually departs from the paradigm that no one is perfect, and is able to forgive perfectly. In fragility man is able to forgive and accept injury as a wound that requires recovery, and forgiveness is a 'therapetic way' that every victim of injury needs. Interpersonal forgiveness even though it is not perfect becomes a priority that needs to be accustomed and trained by everyone, for the sake of the integrity of interpersonal relationships in everyday life. Interpersonal forgiveness is a meeting point that accommodates the remaining wounds, bitterness, and anger.
\end{abstract}

$\begin{array}{ll}\text { How to cite: } & \text { Bachri, D., (2021) Pemberian Pengampunan Antarpribadi Menurut Everett L. Worthington dan Charles L. } \\ & \text { Griswold. Syntax Idea, 3(9), https://doi.org/10.36418/syntax-idea.v3i9.1489 } \\ \text { E-ISSN: } & \text { 2684-883X } \\ \text { Published by: } & \text { Ridwan Institute }\end{array}$


Keywords: interpersonal forgiveness, imperfect forgiveness (non-paradigmatic forgiveness), moral virtues, habitus

\section{Pendahuluan}

Pandemi Covid membuat manusia sehari-hari banyak berinteraksi dengan anggota keluarga di rumah. Tidak jarang interkasi tersebut menimbulkan korban, adanya pihak yang merasa terluka atau membangkitkan perasaan sakit-hati dan terluka yang dulu pernah dialami individu penyintas. Keseharian hidup manusia, luka dan sakit hati kerapkali tidak terhindari. Setiap pribadi bisa mengalami percideraan, dan menjadi korban kejahatan. Korban percideraan perlu menaggapi dengan memberi pengampunan antarpribadi. Ironisnya, betapapun mulianya kandungan kata 'mengampuni', tindakan mengampuni beresiko. Kejahatan muncul dan korban dirugikan pada saat bersedia mengampuni dan berekonsiliasi. Temuan yang disinyalir Worthington bahwa istri meninggal setelah mengampuni suaminya, menjadi catatan kelam (Jr Worthington, 2013).

Berangkat dari keprihatinan terdapat luka serta kepahitan pada korban kekerasan, dilakukan penelitian lapangan dengan kajian psikologi mengambil teori pengampunan antarpribadi Worthington. Penelitian terhadap perempuan yang menjadi korban kekerasan pada masa anak memperlihatkan hasil, bahwa tidak mudah memberi pengampunan antarpribadi (Setiawan \& Rakhmawaty, 2014). Adapun definisi kekerasan terhadap perempuan yang dijadikan pedoman tulisan ini, sesuai dengan yang dimaksud dalam "Deklarasi Penghapusan Kekerasan Terhadap Perempuan" yaitu: "Setiap perbuatan berdasarkan perbedaan jenis kelamin, yang berakibat atau mungkin berakibat kesengsaraan atau penderitaan perempuan secara fisik, seksual, atau psikologis, termasuk ancaman perbuatan tertentu, pemaksaan atau perampasan kemerdekaan secara sewennag-wenang baik yang terjadi di depan umum maupun dalam kehidupan pribadi “ (Pasal1 Deklarasi Penghapusan Kekerasan Terhadap Perempuan, Perserikatan Bangsa-Bangsa, 1993).

Dalam kaidah umum secara moral kita pahami bersama bahwa tindakan mengampuni orang lain yang sudah bersalah kepada kita adalah suatu kebaikan. Namun, jika tindakan baik itu dapat disalahgunakan dan dapat berakibat buruk, berarti dibutuhkan penelitian lebih lanjut. Alasan inilah yang membawa penulis memandang perlunya suatu penelitian filosofis, sebab kajian filsafat selalu bermaksud memberikan sumbangan pemikiran guna menjadi pedoman dalam berkiprah di masyarakat. Penelitian pengampunan antarpribadi yang penulis lakukan menggunakan metode kepustakaan, sebagai upaya menanggapi Worthington yang sejak 1997 telah mengkampanyekan pentingnya penelitian tentang pemberian pengampunan antarpribadi.

Berangkat dari permasalahan tidak mudah mengampuni pelaku kejahatan dalam penelitian penulis berdasarkan teori psikologis Worthington, maka selanjutnya penanganan permasalahan memberi pengampunan perlu diperdalam lewat kajian antropologis-etis. Guna mendiskusikan kajian psikologi dalam terang antropologis, 
penulis mengambil kajian filosofis. Charles Griswold, filsuf Amerika abad 21. Griswold memandang pengampunan antarpribadi dibutuhkan karena pengampunan merupakan masalah keseharian manusia. Penulis bermaksud mencari sejauh mana filsafat dan psikologi memahami kesulitan mengampuni antarpribadi, sehingga manusia dalam kerapuhannya dapat bersikap optimal.

\section{Metode Penelitian}

Pada kajian psikologi, penulis melakukan penelitian dengan pendekatan kualitatif menggunakan metode wawancara mendalam disertai observasi terhadap tiga perempuan usia dewasa muda yang menjadi korban kekerasan pada masa anak. Penelitian dilakukan dengan mengambil teori psikologi Worthington untuk mencari adakah pemberian pengampunan antarpribadi terjadi dalam diri ketiga responden penelitian.

Varian ketiga responden yang dipilih penulis adalah varian agama atau keyakinan imannya (masing-masing: Islam, Kristen Protestan dan Katolik), dan varian prilaku kekerasan berulang dari beberapa pihak meliputi: orangtua (ayah maupun ibu), dan orang yang dituakan: paman maupun kakak, serta seorang sahabat ayah yang sudah diterima sebagai keluarga. Dan sebagai varian tambahan: 2 dari 3 responden mengalami kekerasan seksual di usia $>5$ tahun dari pihak keluarga atau orang yang sudah diterima sebagai keluarga.

Selanjutnya sebagai kesamaan dari ketiga responden sebagai berikut:

1. Korban mengalami kekerasan pada masa usia anak ( $<18$ tahun) dengan frekwensi hampir setiap hari.

2. Pelaku kekerasan adalah keluarga atau orang yang sudah dianggap keluarga (significant others).

3. Korban mengalami peristiwa kekerasan dalam kurun waktu 5 (lima) tahun atau lebih, baik kekerasan fisik, verbal maupun seksual.

4. Pada saat penelitian dilakukan, usia korban berada dalam rentang dewasa muda $(>21$ tahun), tepatnya I: 27 tahun, A: 22 tahun, dan T: 24 tahun.

5. Ketiga responden sangat tersakiti secara psikis dan berusaha berdamai dengan diri sendiri dan pihak pelaku kejahatan (transgressor)

Penelitian kedua disusun berdasarkan temuan penelitian lapangan dalam kajian psikologi sosial yang penulis lakukan (tahun 2004). Sebagai tindak lanjut penelitian lapangan dilakukan penelitian berdasarkan kajian filsafat dengan mengambil metode kepustakaan. Penelitian yang penulis lakukan mengambil teori dan eksplorasi filosofis Charles Griswold dalam beberapa buku yang membahas pengampunan antarpribadi. Pengampunan antarapribadi menurut Griswold berada dalam suatu paradigma bahwa manusia bersalah terhadap sesamanya (Nearly everyone has wronged one another) (Griswold, 2007). Tujuan penelitian dengan mengambil kajian filsafat, untuk menjelaskan sejauh mana ketidak-mampuan memberi pengampunan atau ketidakbersediaan mengampuni secara antarpribadi dapat dipahami dalam terang antropologis etis. 


\section{Hasil dan Pembahasan}

Pada penelitian psikologi berdasarkan teori pengampunan Worthington (E. .. Worthington, 2003), disusun proses pengampunan sebagai berikut:

1. Membuka luka (Recall the hurts)

2. Berempati (Emphatize with the one who hurts you)

3. Memberi pengampunan sebagai suatu pemberian altruistik (Altruistic gift of forgiveness)

4. Berkomitmen menyatakan kesediaan memberi pengampunan (Commit publicy to forgive)

5. Memegang teguh komitmen mengampuni (Hold on to forgiveness)

Hasil penelitian lapangan dan menjadi simpulan penelitian berdasarkan teori Worthington, penulis mendapati:

1. Perempuan dewasa muda yang telah menjadi korban kekerasan pada masa anak belum mampu memberi pengampunan secara total (interpersonal/ antarpribadi maupun intrapsikis/ di dalam hati) sehingga didapati hanya pengampunan tampak luar (Hollow forgiveness). Adapun pengampunan tampak luar yang dangkal dinyatakan dengan kesediaan misalnya: menanda-tangani perjanjian damai, bergandengan tangan atau pun berjabat-tangan, dilakukan antara pihak korban dan pelaku kejahatan (transgressor dan bukan sekadar wrongdoer)

2. Tidak didapatinya pengampunan total karena pelaku kekerasan tidak menyesali perbuatan atau sikapnya, serta proses memberi pengampunan sendiri bukanlah hal yang mudah dilakukan korban, sekalipun secara pribadi sudah berkeputusan memberi pengampunan dan berada atau memposisikan diri sebagai penyintas.

3. Agama bagi sebagian responden berperan sebagai social facilitator, mengingat ajaran dan nilai-nilai yang dimiliki sebagai keyakinan mendorong umat untuk tidak membalas kejahatan dengan kejahatan ataupun mendendam terhadap pelaku kejahatan. (Religio -dalam bahasa Latin-penulis pahami sebagai semacam pagar yang membatasi prilaku manusia untuk senantiasa melakukan kebaikan). Agama juga bisa membawa korban melakukan permenungan mendalam (reframing) jika kemudian ia mendapati dirinya kotor (baca: berdosa) maka secara khusus pada korban kekerasan seksual memandang dirinya tidak patut diampuni (- dalam terang agama tertentu dari responden penulis -). Dalam pemahaman demikian, subyek penelitian yang mengalami kekerasan seksual pun tidak bersedia mengampuni pelaku kekerasan terhadap dirinya.

Penelitian lanjutan dalam kerangka filosofis Griswold, didapati adanya ambang batas sebagai layak diampuni atau memungkinkan untuk diberi pengampunan antarpribadi. Griswold mendapati paradigma pengampunan sedemikian inklusif sehingga hampir tidak ada hal yang tidak terampuni. Dalam bukunya Griswold membedakan antara tak terampuni dari tak mungkin diampuni. Pembantaian NAZI menjadi contoh kejahatan yang massif, terencana, disengaja terhadap sekian ribu orang 
Yahudi; tergolong tidak mungkin diampuni. Pada hakekatnya pengampunan menghargai dan menghormati semua orang, sehingga Griswold memandang setiap individu layak diampuni, sebab tiap orang dapat melakukan transformasi dan berefleksi diri. Penelusuran pemikiran filosofis Griswold ini memberi kemungkinan adanya pemberian pengampunan bagi pelaku kejahatan, dari pihak korban, dengan tujuan demi kesejahteraan subyek yang telah mengalami luka, kepahitan dan terciderai secara psikis maupun fisik.

Pengampunan antarpribadi dalam pandangan filosofis Griswold menaruh hormat kepada setiap individu, betapapun salah dan jahatnya seseorang. Dengan demikian pengampunan sendiri mengandaikan manusia yang sedemikian rapuh, namun mampu bangkit karena setiap orang berharga dan dapat diampuni (The 'common frailty' thesis might just as well lead to vieuw that it is all the more important-just because we are so frail -to hold ourselves and each other accountable by not forgiving (Griswold, 2007).

Diskusi tentang memberi pengampunan antarpribadi menjadi menarik dan dibutuhkan, mengingat berbagai permasalahan hidup sehari-hari membutuhkan kesediaan individu menanggapi dengan memberi pengampunan anatarpribadi. Beberapa contoh yang diangkat Worthington antara lain seputar kehidupan keluarga, sesuai dengan latar-belakang Worthington sebagai konselor pernikahan. Ia memandang perceraian suami-istri dapat dihindari, asalkan ada kesediaan memberi pengampunan antarpribadi. Sedangkan Griswold membahas berbagai situasi tidak ideal yang tidak dapat diubah sehingga membutuhkan pemberian pengampunan, antara lain:

1. Kondisi pelaku kejahatan ataupun korban yang sudah sangat terganggu jiwanya, sudah sakit parah atau pun sudah meninggal dunia.

2. Pengampunan terhadap pelaku kejahatan yang korbannya sudah meninggal dunia biasanya pengampunan diberikan oleh pihak keluarga korban- sebagai pihak ketiga.

3. Pengampunan terhadap diri sendiri.

Keadaan dunia yang tidak ideal atau tidak sempurna, membawa manusia berada dalam penderitaan sehingga kejahatan terjadi, dan pelaku kejahatan membaca peluang atau kesempatan tersebut sehingga menjadikan pihak lain sebagai korban kejahatan. Kondisi keluarga di mana anak-anak dibesarkan oleh orangtua yang pecandu NAPZA, kehilangan kendali karena temperamental, dan berbagai keadaan yang tidak diharapkan terjadi, sehingga dibutuhkan kesediaan serta tekad yang kuat untuk memberi pengampunan antarpribadi.

Dalam pembahasan Griswold dengan merujuk Butler, maka proses memberi pengampunan dimungkinkan dengan langkah terstruktur sebagai berikut:

Pertama, berbagi kemarahan (Butler mengusulkan dengan menyusun narasi), sedang pada Griswold, selain narasi maka dilanjutkan dengan sikap bersimpati terhadap pelaku kejahatan. Dalam pemahaman Griswold, pilihan jatuh pada kesediaan tetap memberi pengampunan, sekalipun memandang pengampunan sebagai kemustahilan (Griswold, 2007). 
Kedua, setelah melakukan hal diatas maka sekarang terbuka dua kemungkinan; alternatif pertama, korban menolak mengampuni pelaku kejahatan. Sebagai pihak konselor yang mendampingi korban atau penyintas, dapat bersikap: netral (standing to do so), tetap peduli dan memperhatikan korban, dan meminta korban agar bersedia menuliskan narasi lagi untuk kesekian kalinya. Menulis narasi diharapkan menjadi 'jalan' untuk korban menjadi merasa lebih nyaman (bandingkan dengan langkah pertama dalam proses pengampunan Woerthington: recall the hurts). Alternatif kedua, diharapkan Griswold menjadi pilihan setiap individu yang bersedia belajar memberi pengampunan antarpribadi. Pengampunan antarpribadi mengandaikan suatu pengampunan yang tidak ideal atau tidak sempurna sebab sesungguhnya setiap orang bersalah terhadap sesamanya, sehingga pemberian pengampunan sendiri tidak sempurna (non-paradigmatic forgiveness)

\section{Kesimpulan}

Penelitian dengan mengambil kajian filosofis berdasarkan eksplorasi pemikiran Griswold memperlihatkan terbuka kemungkinan untuk subyek diampuni dan memberi pengampunan. Pelaku kekerasan merupakan subyek yang layak diampuni, dengan tetap memberlakukan peraturan dan sanksi sesuai hukum yang berlaku. Korban kekerasan sebagai subyek yang mengalami percideraan, dirugikan, sebagai pihak yang terluka dan marah, diharapkan tidak melakukan pembalasan dendam serta berusaha moving out (move forward) atau mengubah posisinya dari korban menjadi penyintas dengan cara memilih memberi pengampunan antarpribadi. Sekalipun pengampunan yang diberikan seorang penyintas belum ideal sebagaimana pengampunan total dalam teori psikologi Worthington, tetap bisa diterima pengampunan yang tidak sempurna itu sebagai pengampunan antarpribadi, demikian menurut pemikiran filosofis Griswold.

Sumbangan pemikiran filsafat selalu berciri umum, menyeluruh dan mendasar. Setelah penulis menyimak berbagai persoalan dalam keseharian hidup manusia, maka penulis memandang tidak bisa dipungkiri bahwa pengampunan dibutuhkan. Lebih jauh melalui penelitian ini penulis memandang perlu mengusulkan pengampunan antarpribadi sebagai habitus yang penting dalam kehidupan sehari-hari karena dua hal: Pertama, luka dan sakit-hati membutuhkan penyelesaian dan pencarian solusi; Kedua, sebagai suatu prinsip moral, penulis memahami pengampunan adalah suatu pilihan yang baik dari sisi etis dan dibutuhkan sebagai suatu tindakan pragmatis-praktis dengan mengutamakan azas kemanusiaan. Dengan mengambil pemahaman Griswold, bahwa tidak ada manusia yang luput dari berbuat salah dan melakukan kejahatan terhadap sesamanya, maka pengampunan merupakan suatu keutamaan moral (virtue) karena itu, penulis memahami memberi pengampunan perlu dilatih menjadi suatu kebiasaan.

Dalam diri individu, sepanjang hidupnya akan terus mengalami merasa terluka dan terciderai oleh sesamanya. Kondisi yang sedemikian rapuh inilah yang membuat Griswold memahami bahwa pemberian pengampunan harusnya berjalan terus, sepanjang hidup manusia, sekalipun prosesnya belum selesai. Pengampunan merupakan suatu paradigma ideal, di mana perubahan hati dan perubahan emosi dialami 
individu penyintas. Proses waktu dan kesediaan menarasikan peristiwa menyakitkan menjadi jalan panjang pemberian pengampunan yang sempurna. Sementara yang sempurna itu belum datang, maka perlu diterima pengampunan sepihak sekalipun tidak ideal menjadi bagian dari dilahirkannya pengampunan antarpribadi. Griswold memandang pengampunan antarpribadi yang dihasilkan merupakan pengampunan tidak sempurna atau tidak ideal (non-paradigmatic forgiveness). Sampai waktunya yang sempurna itu datang, mari bertekun, melatih diri mengampuni sesama dan menata emosi serta menerima luka.

Kebaruan penelitian ini memperlihatkan bahwa pengampunan menjadi suatu titik temu masih dirasakan perasaan terluka dan kemarahan yang tersisa. Seorang penyintas yang sanggup memberi pengampunan memperlihatkan dirinya menempatkan diri sebagai individu yang berani berpengharapan dan mampu berjuang menyatakan kebajikan. Sebagai penutup, akhirnya penulis kembali pada pemahaman bahwa mengampuni adalah tindakan terpuji, dan dengan mengingat pengampunan merupakan suatu pemberian, maka tanpa harus menunggu terluka ataupun sakit-hati, setiap manusia perlu dilatih mengampuni sesamanya. Pembiasaan (pembentukan habitus dilakukan dalam keluarga dan juga komunitas) atau latihan untuk bersedia memberi pengampunan antarpribadi dibutuhkan sehingga manusia berkarakter baik. Salah satu keutamaan (virtue) moral, yang perlu terus ditumbuhkan adalah memberi pengampunan antarpribadi.

\section{BIBLIOGRAFI}

Bedell, T.M. (2002) The Role of Religiosity in Forgiveness, Unpublished Doctoral Dissertation, The Ohio State University.

Bachri, D. (2004) Pemaafan pada Perempuan Dewasa Muda Korban Kekerasan di Masa Anak, tidak diterbitkan, Tesis Psikologi Sosial Fakultas Psikologi Universitas Indonesia.

Campbell, Sue. (2014) Our Faithfulness to the Past, New York: Oxford University Press. Google Scholar

Cousineau, Phil. (2011) Beyond Forgiveness: Reflection on Atonement, Healing the Past, Making Amends, and Restoring Balance in Our Lives and World, San Francisco: JosseyBass A Wiley Imprint. Google Scholar

Disley, Liz. (2015) Hegel, Love and Forgiveness, London: Pickering \& Chatto Publisher.

Duffy, Maria. (2009) Paul Ricoeur's Pedagogy of Pardon: A Narrative Theory of Memory and Forgetting, UK: Continuum. Google Scholar

Erfani, Farhang (2011) Paul Ricoeur Honouring and Continuing All Work, London: Lexington Books. 
George, Theodore. (2011) "Forgiveness, Freedom, and Human Finitude in Hegel's Spirit of Christianity and Its Fate," International Philosophical Quarterly, vol 51, no 1 h. 39-53. Google Scholar

Griswold, Charles. L. (2007). Forgiveness A Philosophical Exploration. New York: Cambridge University Press. Google Scholar

Griswold, Charles. L , (2011), Ancient Forgiveness: Classical, Judaic, and Christian, USA: Cambridges University Press. Google Scholar

Helmick, R.G.\& Peterson, R.L. (2001) Forgiveness and Reconcilliation, Pensylvania: Templeton Foundation Press.

Jonas, L. Geogory (2000) "Crafting Communities of Forgiveness", Interpretation (April, h. 121-134. Google Scholar

Nussbaum, Martha C. (2016) Anger and Forgiveness: Resentment, Generosity, Justice, USA: Oxford University Press. Google Scholar

Konstan, David. (2010) Before Forgiveness: The Origin of Moral Idea, USA: Cambridge University Press. Google Scholar

KNG Long (2020) Forgiveness of Other and Subsequent Health and Wellbeing in Mind-Life A Longitudinal Study on Female Nurses- BMC Psychology Google Scholar.

Lichtenfeld, S, Maier, M.A...Capo, F.A. (2019) The Influence of Decisional and Emotional Forgiveness on Attribution -NCB. Google Scholar.

Marks, M.J. (2013) A Function of Forgiveness: Exploring The Relationship Between Negative Mood and Forgiving- SAGE Journals Google Scholar.

Oliver, Kelly (2003). “Forgiveness and Subjectivity.” Philosophy Today “Fall h. 280-292.

Pattigrove, Glenn (2007). "Forgiveness and Interpretation", Journal of Religious Ethics 35.3, h. 429-452. Google Scholar

Ricoeur, Paul. (2000) The Just. terj. David Pellaur, Chicago dan London: The University of Chicago Press.

Ricoeur, Paul. (2004) Memory, History, Forgetting, terj. Kathleen Blamey, David Pellaur, Chicago dan London: The University of Chicago Press, Google Scholar

Schimmel, S. (2002) Wounds Not Heal by Time: The Power of Repentance and Forgiveness, New York: Oxford University Press. Google Scholar

Szablowinski, Zenon (2010). "Between Forgiveness and Unforgiveness" HeyJ LI (Journal Compilation Roman Catholic Theological Issue) h. 471-482. Google Scholar

Tower, C.C, (2002) Understanding Child Abuse and Neglect, Boston: Allyn and Bacon.

Voiss,J.K. (2015) Rethinking Christian Forgiveness: Theological, Philosophical and Psychological Exploration, Minnesota: Liturgical Press. Google Scholar 
Walker, Rebecca L. Phillip J. Ivonhoe, (2007) Working Virtue, Virtues Ethics and Contemporary Moral Problems, New York: Clarendon Press-Oxford. Google Scholar

Weisband, Edward. (2009) "On the Aporetic Borderline of Forgiveness: Bereavement as a Political Form" Alternatives "34, USA: Dept. of Political Science h. 359-381. Google Scholar

Worthington, E.L. \& Wade N.G. (1999) The Psychology of Unforgiveness and Forgiveness, and Implication for Clinical Practise, Journal of Social and Clinical Psychology, 18/4, 385-418. Google Scholar

Worthington, E.L.(2003) Forgiving and Reconciling (revised ed.) Illinoiss: Interfarsity Press.

Worthington, E.L. (2006) Forgiveness and Reconciliation Theory and Application. London: Routledge. Google Scholar.

Worthington, E.L. Jr. (2005) Handbook of Forgiveness, New York: Routledge, Taylor \& Francis Group.

Worthington, E.L., Sandage. J.S. (2016) Forgiveness and Spirituality in Psychotherapy: A Relational Approach, Washington DC: American Psychological Association. Google Scholar

Worthington, E. (2018) Forgiveness Google Scholar DOI: 10.1093/OBO/979099828340-0208.

Zechmeister, J.S. \& Romero, C. (2002) Victim and Offender Accounts of Interpersonal Conlict: Aoutobiographical Narratives of Forgiveness, Journal of Personality and Social Psychology 82:4, 675-686. Google Scholar

\section{Copyright holder:}

Diana Bachri (2021)

\section{First publication right:}

Syntax Idea

This article is licensed under:

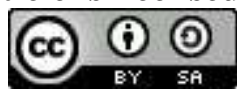

